\title{
Effects of Gonadotropin Administration and Transplantation of the Pituitary Gland on Incidence of Implantation in Immature Rats
}

\author{
Isao Ishibashi, Tetsuro Abe, Yuichiro NishifU JI \\ and Tetsuyuki SugA \\ Department of Veterinary Science, Faculty of Agriculture, \\ Yamaguchi University, Yamaguchi 753
}

(Accepted for publication November 30, 1987)

\begin{abstract}
Summary. This investigation was carried out to examine the effect of treatment with PMSG alone or combined PMSG and hCG by the dose dependent manner on incidence of implantation in immature rats. Also superfecundity was explored by the transplantation of the pituitary gland under the kidney capsule.

In the present study, incidence of pregnancy decreased from $73.3(80-90) \%$ in rats treated with 10 IU of PMSG (or PMSG and hCG) to 6.7 (6.7-13.3) \% of 40 IU-treated ones. The number of implantation sites per pregnant (per mated) rat treated with PMSG alone also decreased from 12.2 (10.4) to $9.0(0.6)$ in a dose dependent manner. Administration of 20 IU of hCG in combination with the same dose of PMSG affected on the number of implantation sites per mated rat. Prolactin injection (5-15 IU/day) during 1 to 7 days of pregnancy in rats treated with 20 IU of GTH had no effect on improvement of implantation. In contrast, when immature rats induced to superovulate by transplantation of the pituitary gland under the kidney capsule, higher pregnancy rates $(80-90 \%)$ and the number of implantation sites (19.3-20.4/pregnant rat; $16.3-17.3 / \mathrm{mated}$ rat) were obtained.

From these resul:s, it is suggested that the cause of diminished implantation in immature rats treated with high doses of $\mathrm{GTH}$ may be due to the loss of embryos from the uterus by accelerated transport, however, further studies are need to verify this presumption. KEY WORDS; IMMATURE RAT, GTH, PITUITARY TRANSPLANTATION, IMPLANTATION.
\end{abstract}

Jpn J Anim Reprod 34, 26-30, 1988

種々の量の性腺刺激ホルモンの投与又は

下垂体を移植した未成熟ラットの着床

\author{
石橋功・安部 哲朗・西藤 裕一郎・菅 徹行 \\ 山口大学農学部, 753 山口市吉田 1677-1
}

性腺刺激ホルモン（GTH）を投与した未成熟（Cole， 1937; Evans and Simpson, 1940; Wu and Meyer, 1966; Miller and Armstrong 1981-a,b) 及び成熟ラッ ト (Cole, 1937; 石橋ら, 1970; 高橋ら, 1982; Ishibashi and Furukawa, 1986)の着床についての報告は, 高単位
の投与で着床が困難なことを指摘している。未成熟ラッ トの着床についての検討は, 従来 PMSG 単一投与の方 法によって行なわれて居り, かつ投与量との関連におけ る検討も充分ではない。一方，成熟ラットでは PMSG 単一投与による過排卵の誘起は困難であり（Welschen 
and Rutte, 1971; 石橋・青木, 1976)，雄と一晚同居交 配することにより改善されるが，その効果は充分ではな い(Ishibashi and Uchinuno, 1984)。従って PMSGに 対し， IU 表示で $1 / 2$ 量相当以上の hCG の併用が望ま しい（石橋・青木，1976）。

PMSG 40 IU を投与した未成熟ラットの着休の改善に ついて, プロジエステロン $(\mathrm{P})$, エストロジエン $(\mathrm{E})$, 或いは PMSG 抗血清の処置は無効である (Miller and Armstrong, 1982; Walton and Armstrong, 1982)。成 熟ラットではプロラクチンの投与が効果があり（Ishibashi and Frukawa, 1986), 下垂体移植 (鮫島・江藤, 1980) や下垂体抽出物の投与(高橋ら，1987）によっても 高い妊娠率と着床数が得られる。

本研究は, 未成熟ラットに種々の量の PMSG 又は $\mathrm{PMSG}$ と $\mathrm{hCG}$ を投与して，投与量と着床の関係を比 較検討すると共に, 成熟ラットの着床の改善に有効なプ ロラクチンの投与及び下垂体移植の影響についても検討 した。

\section{材料と方法}

供試した動物は Wistar-Imamichi 系ラットを当教室 で累代繁殖したものであり，調節した照明条件下（午前 7 時からの14時間を明るくする）で飼育した。生後30〜 33日齢（出生日を 0 日とする; PMSG 投与又は下垂体 移植時の体重 85〜105 g) の522頭を使用した。そのほか, 下垂体移植の対照群として成熟雌（2.5 3.5力月齢，体 重205 270 g）50頭，及び下垂体の提供には成熟と生後 36〜42日齢の雄各50頭を用いた。

\section{処 置}

ホルモン処置は生後 30〜33日の11：00〜13:00時(h) に，5，10，20又は $40 \mathrm{IU}$ の PMSG を内股部筋肉内に投 与し， $\mathrm{hCG}$ を併用投与するときは， $52 \sim 54 \mathrm{~h}$ 後（生後 32〜35日の $17: 00$ h) に0〜20 IU を投与した。hCG 投 与後又はそれに相当する時刻から雄と同居させ，翌日腟 垢像を検査して，精子の存在により交配を確認した（妊 娠 0 日)。

日量 5 ～15 IU のプロラクチンの投与は, PMSG 20 IU と hCG 0 20 IU を処置した未成熟ラットの妊娠 $1 \sim 7$ 日に内股部筋肉内に行った。未成熟ラットへの下 垂体の移植は，PMSG 投与と同一日歯同時刻に，成熟 ラットでは胵垢像IV期の日の同時刻に，エーテル麻酔で 腎皮膜下へ行った。52〜 $54 \mathrm{~h}$ 後に当る $17: 00 \mathrm{~h}$ ( $\mathrm{LH}$ 放 出時 : Taya et al, 1983) から雄と同居させた。

\section{観 察}

妊娠 8 日に頭部打撲法によって殺し，着床数を数え た。移植下垂体の状態は屠殺時に点検した。

\section{成績の処理}

結果の統計処理は $x^{2}$ 及び $\mathrm{t}$ 検定によった。

\section{結果}

種々の量の GTH を投与した未成熟ラットの妊娠率及 び着床数は Table 1 に示した。すなわち，交配率は 88.7\%(330/372)であり，妊娠率は PMSG（又は PMSG・ hCG）5〜10 IU 投与の 73.3〜76.7(80〜90)\% から，40 IU 投与の $6.7(6.7 \sim 13.3) \%$ ， いずれも有意に低下し た $(\mathrm{p}<0.05 \sim 0.001)$ 。 PMSG に対し，IU 表示で $1 / 2$ 又 は同量の hCG を併用投与した場合の妊娠率は, PMSG 単一投与の場合に比較してやや高い傾向を示したが，有 意な差ではなかった。交配ラット当りの着床数は, PMSG 単一及び PMSG ・ hCG 併用投与群共に, PMSG 量 $5 \mathrm{IU}$ と $10 \mathrm{IU}$ の間には差がなかったが，PMSG 20 IU と $40 \mathrm{IU}$ では PMSG 量 $5 \sim 10 \mathrm{IU}$ 投与に比較して, いずれも有意に低下した $(\mathrm{p}<0.05 \sim 0.001)$ 。ただし $\mathrm{PMSG} \cdot \mathrm{hCG}$ 同量投与の $5 \mathrm{IU}$ と $20 \mathrm{IU}$ 投与の間では 差を認めなかった。また PMSG 単一投与と PMSG・ hCG 併用投与の間では，PMSG 量 $20 \mathrm{IU}$ の間で有意な 差 $(\mathrm{p}<0.05)$ が認められたほかは，いずれも差がなかっ た。な打, 妊娠ラット当りの着床数は, 各投与量間及び $\mathrm{PMSG}$ 単一投与と $\mathrm{PMSG} \cdot \mathrm{hCG}$ 併用投与間のいずれ に扣いても，有意な差が見られなかった。

PMSG 20 IU と hCG 5〜20 IU を投与した未成熟ラ ットの妊娠 $1 \sim 7$ 日に, 日量 $5 \sim 15$ IU のプロラクチン の投与は着床を改善しなかった(Table 2)。

成熟又は未成熟雄ラット下垂体を未成熟雌に移植した とき，成熟ラットの場合同様に，高い妊娠率 (80 90\%) と着床数（妊娠ラット当り 19.3 20.4 個）が得られた (Table 3)。この結果は, 妊娠率及び着床数共に, PMSG • hCG 20 又は $40 \mathrm{IU}$ 投与の場合に比較して有意に高かっ $た(\mathrm{p}<0.05 \sim 0.001)$ 。

\section{考察}

本実験における種々の量の GTH 投与後の交配率は 88.7\% (330/372) であり，成熟ラットの $94.6 \%$ (Ishibashi and Frukawa，1986）に比較して低い。その原因 は雌雄の体格差, 性成熟及び性行動などによると推測さ れるが，詳細は明らかでない。 
Table 1. Incidence of pregnancy and the number of implantation sites in immature rats treated with varying doses of gonadotropins

\begin{tabular}{|c|c|c|c|c|c|c|}
\hline \multicolumn{2}{|c|}{ Doses (IU) } & \multirow{2}{*}{$\begin{array}{l}\text { No. of } \\
\text { rats } \\
\text { used }\end{array}$} & \multirow{2}{*}{$\begin{array}{l}\text { Incidence of } \\
\text { pregnancy }(\%)\end{array}$} & \multicolumn{3}{|c|}{ No. of implantation sites } \\
\hline PMSG & hCG & & & $\begin{array}{l}\text { Per mated } \\
\operatorname{rat}(M \pm S E)\end{array}$ & $\begin{array}{l}\text { Per pregnant } \\
\text { rat }(M \pm S E)\end{array}$ & Range \\
\hline 5 & 0 & 33 & $23 / 30^{1)}(76.7) \mathrm{a}^{2)}$ & $9.7 \pm 1.2 \mathrm{a}^{3)}$ & $12.6 \pm 1.0$ & $2-25$ \\
\hline 10 & 0 & 33 & $22 / 30 \quad(73.7) \mathrm{b}$ & $10.4 \pm 1.4 \mathrm{~b}$ & $14.2 \pm 1.4$ & $6-27$ \\
\hline 20 & 0 & 33 & $(30.0) \mathrm{c}$ & $4.5 \pm 1.5 \mathrm{c}$ & $15.0 \pm 3.0$ & $3-28$ \\
\hline 40 & 0 & 33 & $(6.7) \mathrm{d}$ & $0.6 \pm 0.4 \mathrm{~d}$ & $9.0 \pm 2.8$ & 7,11 \\
\hline 5 & 5 & 37 & $(80.0) \mathrm{e}$ & $9.2 \pm 1.2 \mathrm{e}$ & $11.6 \pm 1.0$ & $4-26$ \\
\hline \multirow[t]{2}{*}{10} & 5 & 33 & $(80.0) \mathrm{f}$ & $12.1 \pm 1.5 \mathrm{f}$ & $15.1 \pm 1.3$ & $3-28$ \\
\hline & 10 & 34 & $(90.0) \mathrm{g}$ & $12.7 \pm 1.4 \mathrm{~g}$ & $13.8 \pm 1.3$ & $2-29$ \\
\hline \multirow[t]{2}{*}{20} & 10 & 35 & $(33.3) \mathrm{h}$ & $4.2 \pm 1.3 \mathrm{~h}$ & $12.6 \pm 2.1$ & $1-21$ \\
\hline & 20 & 34 & $(53.3) \mathrm{i}$ & $8.0 \pm 1.7 \mathrm{i}$ & $15.0 \pm 1.8$ & 4-28 \\
\hline \multirow[t]{2}{*}{40} & 20 & 33 & $(6.7) \mathrm{j}$ & $1.2 \pm 0.9 \mathrm{j}$ & $18.5 \pm 5.0$ & 15,22 \\
\hline & 40 & 34 & $(13.3) \mathrm{k}$ & $1.2 \pm 0.6 \mathrm{k}$ & $8.8 \pm 2.0$ & $5-13$ \\
\hline
\end{tabular}

1) No. of pregnant rats/No. of mated rats. The percentage of mated rats was $88.7 \%(330 / 372$, 81. 1-93. 8\%).

2) $\mathrm{p}<0.05:$ e, f vs $\mathrm{i}$; c vs d. $\mathrm{p}<0.01: \mathrm{h}$ vs $\mathrm{j}$; i vs g, k, $\mathrm{p}<0.001$ : a, b vs c, d; e, f, g vs h, j, k; i vs j.

3) $\mathrm{p}<0.05: \mathrm{c}, \mathrm{g}$ vs i. $\mathrm{p}<0.01: \mathrm{a}, \mathrm{b}$ vs c. $\mathrm{p}<0.001$ : a, b vs $d$; e, g, i vs k; f vs $h$, j.

Table 2. Effect of prolactin injection on incidence of pregnancy and the number of implantation sites in immature mated rats pretreated with 20 IU of PMSG followed by 0 to 20 IU of hCG

\begin{tabular}{|c|c|c|c|c|c|c|}
\hline \multicolumn{3}{|c|}{$\operatorname{Doses}(\mathbf{I U})$} & \multirow{2}{*}{$\begin{array}{l}\text { Incidence of } \\
\text { pregnancy }(\%)\end{array}$} & \multicolumn{3}{|c|}{ No. of implantation sites } \\
\hline PMSG & hCG & Prolactin & & $\begin{array}{l}\text { Per mated } \\
\text { rat }(M \pm S E)\end{array}$ & $\begin{array}{l}\text { Per pregnant } \\
\text { rat }(M \pm S E)\end{array}$ & Range \\
\hline \multirow{6}{*}{20} & \multirow[t]{2}{*}{0} & 5 & $2 / 15(13.3)^{1)}$ & $2.0 \pm 1.7$ & $15.0 \pm 14.1$ & 5,25 \\
\hline & & 10 & $4 / 15(26.7)$ & 5. $9 \pm 2.9$ & $22.3 \pm 5.1$ & $10-31$ \\
\hline & \multirow[t]{2}{*}{10} & 10 & $7 / 15(46.7)$ & $6.3 \pm 2.4$ & $13.4 \pm 3.5$ & $1-25$ \\
\hline & & 5 & $3 / 15(20.0)$ & $5.3 \pm 3.0$ & $26.3 \pm 5.5$ & $20-35$ \\
\hline & \multirow[t]{2}{*}{20} & 10 & $6 / 15(40.0)$ & $5.9 \pm 2.2$ & $14.7 \pm 2.7$ & $11-27$ \\
\hline & & 15 & $2 / 15(13.3)$ & $3.5 \pm 2.5$ & $26.0 \pm 5.7$ & 22,30 \\
\hline
\end{tabular}

1) See the legend of Table 1 .

PMSG 5～10 IU 投与の妊娠率 73.3〜 76.7\%は, 諸氏 の PMSG 処置 (Cole, 1937; Wu and Meyer, 1966; Miller and Armstrong, 1981-a) 及び FSH 処置(Evans and Simpson, 1940) の成績とほぼ一致した。本実験に おける PMSG · hCG 5 10 IU 投与の妊娠率は, PMSG 単一投与のそれに比較してやや高いが有意な差ではな く，20〜40 IU 投与でも同様の傾向にあった。また $\mathrm{PMSG} \cdot \mathrm{hCG} 20 \mathrm{IU}$ 投与の交配ラット当りの着床数は, PMSG 単一投与の場合より高かった $(\mathrm{p}<0.05)$ 。これ らの結果は, 未成熟ラットに扎いても, 成熟ラットの場 合同様に，雄と一晚同居交配することにより，過排卵の
誘起が改善されるとしても充分ではなく (Ishibashi and Uchinuno, 1984), hCG の併用投与が望ましい(石橋・ 青木，1976）ことを示すものであろう。

$\mathrm{PMSG}$ 又は $\mathrm{PMSG} \cdot \mathrm{hCG}$ 5〜10 IU 投与の着床数(妊 娠ラット当り $11.6 \sim 15.1$ 個) は, 諸氏の PMSG 単一又 は FSH 投与の成績 (Cole, 1937; Evans and Simpson, 1940; Wu and Meyer, 1966)より少ないが, Miller and Armstrong (1981-a) の PMSG 単一投与及び成熟ラット の成績 (Cole, 1937; 不橋ら, 1970; Ishibashi and Frukawa，1986）とほぼ一致した。差違の原因は系統やホル モンに対する感受性，例数の多少などによるのではない 
Tbale 3. Incidence of pregnancy and the number of implantation sites in immature rats after transplantation of the pituitary gland under the kidney capsule

\begin{tabular}{|c|c|c|c|c|c|}
\hline \multirow[b]{2}{*}{ Age of recipient } & \multirow{2}{*}{$\begin{array}{l}\text { Age of pituitary } \\
\text { donor (male) }\end{array}$} & \multirow{2}{*}{$\begin{array}{l}\text { Incidence of } \mathbf{f}^{1,2)} \\
\text { pregnancy }(\%)\end{array}$} & \multicolumn{3}{|c|}{ No. of implantation sites } \\
\hline & & & $\begin{array}{l}\text { Per mated }{ }^{2)} \\
\text { rat }(M \pm S E)\end{array}$ & $\begin{array}{l}\text { Per pregnant }{ }^{2)} \\
\text { rat }(M \pm S E)\end{array}$ & Range \\
\hline Mature & Mature & $23 / 25(92.0)_{+++}^{* *}$ & 19. $4 \pm 1.7_{+++}^{* * *}$ & 21. $1 \pm 1.3_{+++}^{* *}$ & $1 C-31$ \\
\hline Mature & $\begin{array}{c}\text { Immature } \\
\text { (36-42 days) }\end{array}$ & $20 / 25(80.0)_{+++}^{*}$ & 15. $0 \pm 1.2_{+++}^{* *}$ & $18.8 \pm 1.1_{+}$ & $8-26$ \\
\hline $\begin{array}{l}\text { Immature } \\
\text { (30-33 days) }\end{array}$ & Mature & $24 / 30(80.0)_{+++}^{*}$ & 16. $3 \pm 2.0_{+++}^{* *}$ & $20.4 \pm 1.6_{++}^{*}$ & $2-35$ \\
\hline $\begin{array}{l}\text { Immature } \\
\text { (30-33 days) }\end{array}$ & $\begin{array}{c}\text { Immature } \\
(36-42 \text { days })\end{array}$ & $27 / 30(90.0)_{+++}^{* * *}$ & $17.3 \pm 1.5_{+++}^{* * *}$ & $19.3 \pm 1.2_{++}^{*}$ & $5-28$ \\
\hline
\end{tabular}

1) No. of rats with implantation sites/No. of transplanted rats.

2) No significantly different amog 4 groups.

*, **, *** Significantly different at the $5\left({ }^{*}\right), 1\left({ }^{* *}\right)$ or $\left.0.1 *^{* *}\right) \%$ level from rats treated with 20 IU of combined PMSG and hCG in Table 1.

${ }^{++},++$Significantly different at the $1\left(^{++}\right)$or $0.1\left(^{++}\right) \%$ level from rats treated with 40 IU of combined PMSG and hCG in Table 1.

かと推測される。また PMSG 単一及び $\mathrm{PMSG} \cdot \mathrm{hCG}$ 併用投与のいずれの場合に打いても，PMSG 投与量の 増加に伴って娃娠率と着床数が低下した。この傾向は, 未成熟ラットの PMSG 単一投与 (Cole, 1937; Miller and Armstrong, 198-a)及び成熟ラットの GTH 処置の 場合 (Cole, 1937; Ishibashi and Frukawa, 1986) と一 致した。このことは高単位の GTH の投与が異常なホル モン環境を導き(Miller and Armstrong, 1981-b; Walton and Armstrohg, 1981; 石橋ら，1984), 成熟 ラットの場合同様に卵子下降を促進した結果（石橋， 1983）であろうと考えられるが，明確なことは受精と発 育過程などの検討を俟って論及することが適当と思推さ れる。

成熟ラットで有効なプロラクチンによる着床の改善 (Ishibashi and Frukawa，1986) が，未成熟ラットでは 見られなかったが，その原因については明らかではな い。鮫島・江藤 (1980) は生後35～41日齢雄ラットの下垂 体前葉を $3 / 4$ 又は 1 個, 成熟雌ラットの腎皮膜下に移植 して，23.4又は31.2個の着床を得ている。本実験の未成 熟ラットに打いても，成熟ラット同様に高い妊娠率と着 床数が得られたが，彼等の成績に比較すれば着床数がや や少ない。しかし成熟ラットに下垂体抽出物を投与した 高橋ら (1987)の成績と一致する。若干の差違は, ラット の系統, 個体や例数の差, さらに移植時に抢ける下垂体 の取扱いを含む技術的な問題など，種々な要因が影響し ていると推測される。

以上の結果は, GTH の処置が投与量の増加に伴っ
て，未成熟ラットの妊娠率と着床数を低下させることを 示す。その主な原因として，成熟ラットの場合同様に， 卵子下降の促進によることを推測させるものであるが, 詳細については今後の検討を要する。

\section{References}

Cole HH (1937) Superfecundity in rats treated with mare serum gonadotropic hormone. Amer $J$ Physiol 119: 704-712.

Evans HM, Simpson ME (1940) Experimental superfecundity with pituitary gonadotropins. Endocr 27: 305-308.

Ishibashi I, Tanaka H, Takahashi K (1970) Morphological studies on superovulated rats ova, III. early stage of fertilization and implantation in adult rats following gonadotropin treatment. Japan J Anim Reprod 16: 14-19 (in Japanese).

Ishibashi I, Aoki H (1976) Effect of gonadotropins on maturation and ovulation of oocytes in adult rats, I. Effect of various doses on ovulation. Japan J Anim Reprod 21: 130-134 (in Japanese).

Ishibashi I (1983) Number of ovulation, fertilization and early development of ova in adult rats following treatment with various doses of PMSG and hCG. Japan J Anim Reprod 29: 1-7 (in Japanese).

Ishibashi I, Sato K, Ohsawa M (1984) Number of follicles and serum levels of steroid hormone in adult rats which mated following treatment with various doses of PMSG and hCG. Japan J Anim Reprod 30: 199-205 (in Japanese).

Ishibashi I, Uchinuno Y (1984) The stimulating effect 
of copulation in adult rats treated with PMSG alone. Japan J Anim Reprod 30: 233-238.

Ishibashi I, Furukawa T (1986) Incidence of implantation in adult rats treated with gonadotropins and its improvement by exogenous prolactin. Japan J Anim Reprod 32: 188-194.

Miller BG, Armstrong DT (1981-a) Superovulatory dose of pregnant mare serum gonadotropin cause delayed implantation and infertility in immature rats. Biol Reprod 25: 253-260.

Miller BG, Armstrong DT (1981-b) Effects of superovulatory dose of pregnant mare serum gonadotropin on ovarian function, serum estradiol and progesterone levels and early embryonic development in immature rats. Biol Reprod 25: 261-271.

Miller BG, Armstrong DT (1982) Infertility in superovulated immature rats: role of ovarian steroid hypersecretion. Biol Reprod 26: 861-868.

Sameshima H, Etoh T (1980) Superpregnancy induced by a single pituitary gland transplanted beneath the kidney capsule in adul rats. 89th Congr in Japanese Soc Vet Sci Suppl: 37 (in Japanese).

Takahashi J, Honda K, Masaki J (1982) Disturbance of pregnancy and the serum prolactin and progesterone levels in superovulated adult rats. Japan
J Anim Reprod 28: 59-66 (in Japanese).

Takahashi J, Itoh A, Yasuda Y (1987) Induction of superpregnancy by pituitary extract injection in rat. Jap J Fert Ster 32: 327-333 (in Japanese).

Taya K, Mizokawa T, Matsui T, Sasamoto S (1983) Induction of superovulation in prepubertal female rats by anterior pituitary transplants. $J$ Reprod Fert 69: 265-270.

Walton EA, Armstrong DT (1981) Ovarian function and early embryonic development in immature rats given a superovulatory dose of PMSG later neutralized by antiserum. Biol Reprod 25: 272280.

Walton EA, Armstrong DT (1982) Implantation and later fetal development in immature rats given a superovulatory dose of pregnant mare's serum gonadotropin, later neutralized by antiserum. Biol Reprod 27: 841-846.

Welschen R, Rutte M (1971) Ovulation in adult rats after treatment with pregnant mare serum gonadotropin during oestrus. Acta Endocr 68: 41-49.

Wu J-T, Meyer RK (1966) Delayed implantation in gonadotropin-treated immature rats. Proc Soc exp Biol Med 123: 88-91.

生後30～33日齢の未成熟ラットに，種々の量の PMSG 又は PMSG と hCG を投与して，着休に及 ぼす影響を比較検討すると共に，下垂体移植による着床についても調べた。

1）種々の量の GTH を投与した未成熟ラットの交配率は $88.7 \%$ であった。2) PMSG・hCG 5 10 IU 投与の妊娠率(80〜90\%) は PMSG 5 10 IU 投与の場合 (73.3〜76.7\%)に比較してやや高いが, 有意な差ではなかった。20及び $40 \mathrm{IU}$ 投与に扔いても同様の傾向であり，かつ 5 10 IU 投与に比較 して有意 $(\mathrm{p}<0.05 \sim 0.001$ ) 低下した。3） PMSG 及び PMSG・hCG 5 10 IU 投与の妊娠 (交配) ラ ット当りの着床数は, 12.6 14.2(9.7 10.4)及び11.6〜15.1(9.2〜12.7)個であり, 両群間及び投与 量間に有意な差はなかった。しかしながら，PMSG 20 IU と PMSG・hCG 20 IU 投与の間には有意 な差 $(\mathrm{p}<0.05)$ が見られた。4) PMSG 単一及び PMSG ・ hCG 併用投与の場合共に, PMSG 投与量 の增加に伴って，妊娠率及び着床数が有意 $(\mathrm{p}<0.05 \sim 0.001)$ に低下した。5）下垂体移植により，高 い妊娠率 $(80 \sim 90 \%$ ) と着床数(妊娠ラット当り 19.3 20.4個)が得られた。

以上の結果から，GTH 投与量の增加に伴って，妊娠率と着床数が低下寸ることを知ると共に，そ の主な原因として卵子下降の促進による胚の子宮内からの消失が推測された。しかしながら，その詳 細については今後の検討を要する。 